\title{
CHALLENGES FOR \\ NON-AMERICAN-ENGLISH-SPEAKING TEACHERS IN ENGLISH LANGUAGE CLASSROOMS IN BRAZIL
}

\author{
Nilton Hitotuzi ${ }^{1}$
}

\begin{abstract}
In this reflection paper, we discuss the issue of prestige varieties of English mostly in terms of accent preference. Literature points out that American and British English are the varieties dominating English language teaching textbooks around the world. At the same time, literature also suggests that the American variety is predominantly favoured worldwide, especially in Brazil. Furthermore, because of the American linguistic hegemony in this country, non-American-English-speaking teachers of English can be faced with some institutional and pedagogical challenges. Finally, some suggestions on how to cope with "Americanised" classrooms are offered.
\end{abstract}

Keywords: Accent. Hegemony. Non-American-English-speaking teachers. Varieties of English.

DESAFIOS DO PROFESSOR NÃO FALANTE DA VARIANTE ESTADUNIDENSE EM SALAS DE AULA DE LÍNGUA INGLESA NO BRASIL

\section{RESUMO}

Neste artigo reflexivo, aborda-se a questão das variantes da língua inglesa de prestígio principalmente em termos de preferência de sotaque. A literatura aponta para o inglês americano e britânico como variantes predominantes nos livros didáticos para o ensino de inglês em todo o mundo. Ao mesmo tempo, argumenta-se que a variante americana seja favorecida globalmente, especialmente no Brasil. Além disso, como consequência da hegemonia linguística norte-americana nesse país, professores de inglês que não falam inglês americano podem enfrentar alguns desafios institucionais em suas ações pedagógicas. Também são oferecidas algumas sugestões sobre como lidar com a sala de aula "americanizada".

Palavras-chave: Sotaque. Hegemonia. Professores que não falam inglês americano. Variantes de Inglês. 
English is spoken all over the world, and it seems there is no such thing as a standard cosmopolitan variety of English. However, many would agree that there are certain limitations as to the choice of a target variety when it comes to learning English either as a second or a foreign language. Apparently, many language experts assume that learners of English are expected to choose either American English or British English as a target variety for their prestigious status (BROUGHTON et al., 1980; QUIRK; WIDDOWSON; CANTÚ, 1985; BERNS, 2013; BROOK-HART; JAKEMAN; JAY, 2013; ROGERSON-REVELL, 2013; CRUSTTENDEN, 2014; RAY, 2016; LOPRIORE; VETTOREL, 2016). This view seems to polarise with that of learners of English as a second language (ESL), since in this environment learning is a great deal dependent on local variety. If, for instance, a Singaporean learner chooses either one of these prestige varieties of English, he or she might hazard jeopardizing membership of his or her speech community, since neither British nor American English is the target variety in Singapore (BROUGHTON et al., 1980) - Singhlish appears to be a more realistic label for the English spoken in Singapore (COOK, 2016). On the other hand, however, learners of English as a foreign language $(\mathrm{EFL})$ appear to be in a privileged position, insofar as theoretically there are no sociocultural obligations compelling allegiance to the prevailing target variety in their country.

Nevertheless, the "bandwagon effect" regarding variety choice can sometimes be so overwhelming that other varieties of English may be treated as non-standard or not worth learning due to the natural tendency of the region, and other folk linguistic reasons. This problem can render prolific discussions on its serious implications for the ESL and EFL classroom. But, because we draw on our teaching experience in Brazil, this paper will focus only on EFL teaching. Moreover, assuming that the tension involving varieties of English in Brazil is limited particularly to that of pronunciation, two prominent world standard accents will be dealt with hereinafter: (1) the accent with which General American (GA) - the Standard American English - is normally spoken, and (2) Received Pronunciation (RP) ${ }^{2}$ - the accent with which Standard British English is spoken by a stratum of the English society and which is taught at language schools worldwide.

Importantly, the terms variety, dialect and accent are employed throughout this paper in the sense some experts commonly employ them. Variety will thus be treated here within the rather broad boundaries established by Hudson (1980, p. 23-24):

If one thinks of "language" as a phenomenon including all the languages of the world, the term [variety] can be used to refer to different manifestations of it, in just the same way as one might take "music"' as a general phenomenon and then distinguish different "varieties of music". What makes one variety of language different from another is the linguistic items that it includes, so we may define a variety

\footnotetext{
${ }^{2}$ In this paper, RP is used as an umbrella term to represent the continuum that ranges from a more conservative accent (e.g. older members of the Royal Family), through BBC English (e.g. the accent of most anchormen/women from the BBC World television broadcasts) to more innovative accents that represent a new continuum stretching from Near-RP to Estuary English, as Wells (1982) and Altendorf (1999) - both cited in Bayard et al. (2001, p. 28) respectively label them.
} 
of language as a set of linguistic items with similar social distribution. This definition allows us to call any of the following "varieties of language": English, French, London English, the English of football commentaries, the languages used by the members of a particular long-house in the north-west Amazon, the language or languages used by a particular person.

Similarly, the terms dialect and accent will be dealt with in Lyons's (1981, p. 268) sense: "The most obvious difference between the terms 'accent' and 'dialect' is that the former is restricted to varieties of pronunciation, whereas the latter also covers differences of grammar and vocabulary". On the other hand, the term British English is employed here to refer solely to the Standard English of England as a recognition of other European "Englishes" such as Scottish English and Irish English since, as Lyons (1981, p. 270) points out, they "[...] stand in much the same relation to the English of England as American English does". Thus, considering the centrality of these concepts to the discussion of the main questions in this paper, namely (1) problems teachers of English might be faced with in the classroom regarding accent and (2) how to tackle them, some comments on standardisation followed by a brief description of GA and RP will ensue.

\section{THE MATTER OF STANDARDISATION}

Standardisation is a somewhat intricate issue for, whilst being an idealistic concept, it proves to be necessary for the uniformity of any given language and for the unity of the society which communicates through it (LODGE, 1993). This is rather paradoxical though since, as norms are established, and groups of people are unified by them, one speech community becomes privileged to the detriment of others which not surprisingly happen to be mostly halfway down the pyramid of the economic and political power (WARDHAUGH, 1992; LYONS, 1981). Such hegemonic position of the elite of a given society often enhances intolerance of standardisation (WARDHAUGH, 1992; KACHRU; NELSON, 2006; ROMAINE, 2007). Perhaps the main reason for this is the embarrassing line drawn by standardisation between educated and non-educated people:

Standard English is that variety of English which is usually used in print, and which is normally taught in schools and to non-native speakers learning the language. It is also the variety which is normally spoken by educated people and used in news broadcasts and other similar situations. The difference between standard and non-standard, it should be noted, has nothing in principle to do with differences between formal and colloquial language, or with concepts such as "bad language". Standard English has colloquial as well as formal variants, and Standard English speakers swear as much as others (TRUDGILL, 1983, p. 17, as cited in WARDHAUGH, 1992, p. 31; see also RYAN; GILES; SEBASTIAN, 1982).

\section{STANDARD AMERICAN ACCENT: GA}

Essentially, there is no particular accent in the United States that is so conspicuous as to make Standard American English isomorphic at the phonological level. Instead, what linguists have found is a high geographical prominence of some pronunciation traits throughout the American territory. 
In the seventeenth century, when the first colonists from England settled in America, they brought the language spoken by some of the brilliant minds of the time such as William Shakespeare and John Milton. Later, in the nineteenth century, emigrants from Ireland, Germany, Italy, and from other European countries also went to America. As a corollary, the English spoken in the Colony began to undergo some important changes alongside those internal variations normally occurring due to the natural development of languages in general, which is caused by changes in the structure of society (ROBERTSON; CASSIDY, 1954). The perspective of change was so evident that some defenders of national identity such as Noah Webster advocated that America should have an entirely new language "as different from the future language of England, as the modern Dutch, Danish, and Swedish are from the German, or from one another" (WEBSTER, 1789, p. 22, as cited in ROBERTSON; CASSIDY, 1954, p. 377).

According to Baugh and Cable (2005), linguists initially divided the American dialects into three major groups: the New England dialect, the Southern dialect, and General American, which would comprehend other regions of the country. Nevertheless, subsequently to Professor Hans Kurath's A Work Geography of the Eastern United States in 1949, the linguistic map of the United States was redefined into at least six prominent isoglosses (Figure 1) within whose boundaries there seem to be two major contrasting dialects: the Eastern New England versus a sort of speech which is common to large areas of the rest of the country.

Figure 1 - The Dialects of American English

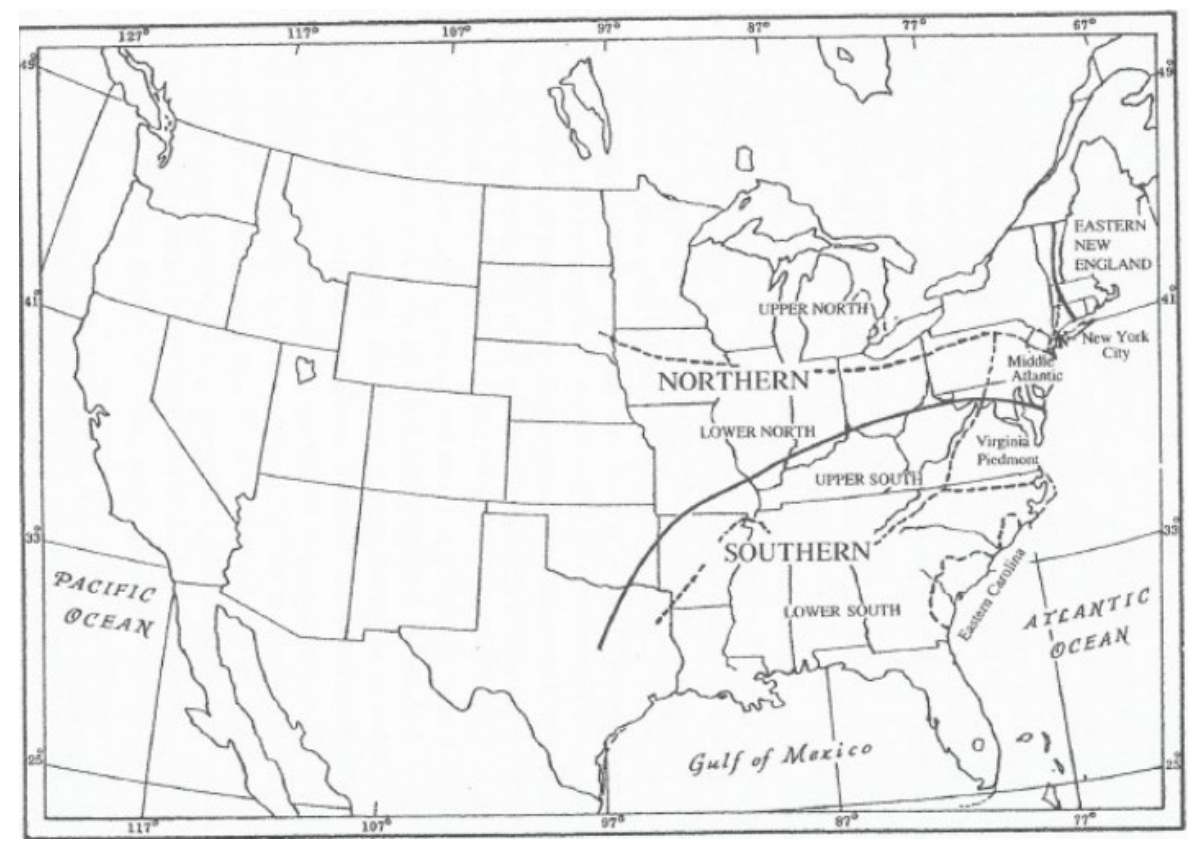

Source: BAUGH; CABLE, 2005, p. 356.

It is probably this "nameless" dialect that occupies the hiatus left in the central and western parts of the United States by GA, as Baugh and Cable (2005, p. 360) suggest: 
[...] if the term [General American] is completely abandoned, something very much like it will have to be invented in the future. ...If the trend toward homogeneity within the vast area of General American continues, there will be less utility in the terms "Northern" and "Midland" for identifying speakers from, say, Minnesota (Northern) and Southern lowa (Midland) than in the supplanted term "General American," [...]

Thus, assuming that GA can label the prestige North American dialect, which in turn is normally taught at language schools throughout the world, this term can be conveniently used to refer to the accent with which this Standard American dialect is often spoken, according to Lyons's (1981) concepts of accent and dialect. At this point, one should be quick to point out that this homonymy does not put GA on the same standing as RP, since far from having the status of standard dialect, the latter is but one of the accents with which Standard British English is spoken, as suggested by Hudson (1980; see also LYONS, 1981, p. 272-273)

[...] in Britain we may say that many people use a regional accent but standard dialect, and a select few use an RP accent with the same standard dialect. Great confusion results if the standard dialect, which is a matter of vocabulary, syntax and morphology, is referred to as "RP" (HUDSON, 1980, p. 44).

Several features can mark the boundaries of a given accent and, as far as the GA accent is concerned, at least four salient features appear to differentiate it from those of other English-speaking countries: (a) the non-pre-vocalic /r/ (e.g. car); (b) the intervocalic/t// flapping (e.g. lettuce); (c) the yod-dropping (e.g. new /nu:/); and (d) the long /a:/ in words like hot, pot and rock (TRUDGILL, 1986; LADEFOGED; JOHNSON, 2011).

\section{STANDARD BRITISH ACCENT: RP}

Standard British accent seems to have a unique status in relation to many other pronunciation standards around the world. For one thing, whilst in some countries the national standard sound systems are somehow undefined due to great uniformity amongst regional variants, in England there is an outstanding accent that is markedly considered the standard spoken English of the English. For another, it also differs from other spoken standards in that it is rather a social class badge than a geographically hegemonic accent, as Abercrombie (1965) puts it (See also SKANDERA; BURLEIGH, 2011; ROGERSON-REVELL, 2013):

This state of affairs is something which is either unsuspected, or misunderstood, outside England - partly because, although English people are generally aware of the situation, they do not mention it much. As a matter of fact it is rather an embarrassing subject. It is not easy to talk about it without hurting people's feelings, because although R. P. is not the accent of a region of England, it is the accent of a social class, and embarrassment starts as soon as it is asked who speaks with this Received Pronunciation, and who does not (ABERCROMBIE, 1965, p. 12).

\footnotetext{
${ }^{3}$ It seems important to point out that Baugh and Cable (2005) follow Lyons's (1981) definition of the term dialect, whereas Hudson appears not to have the phonological aspect in mind when using it. 
Back in the eighteenth century, the issue on "accent-bar" raised by Abercrombie (1965) had already a clear-cut dimension, and prejudice against other accents was equally apparent.

According to Strang (2015), in Restoration drama, the accent and other characteristics of peasants were vehemently disdained. Nevertheless, it is worth pointing out that, back in 1770, the standard spoken English of England had a foot in regional features. According to Baugh and Cable (2005), the East Midland district was the key contributor to the formation of RP, London, the metropolis, being its focal area (Figure 2). RP has undergone various types of changes, since that time though (STRANG, 2015).

Figure 2 - The dialects of Middle English

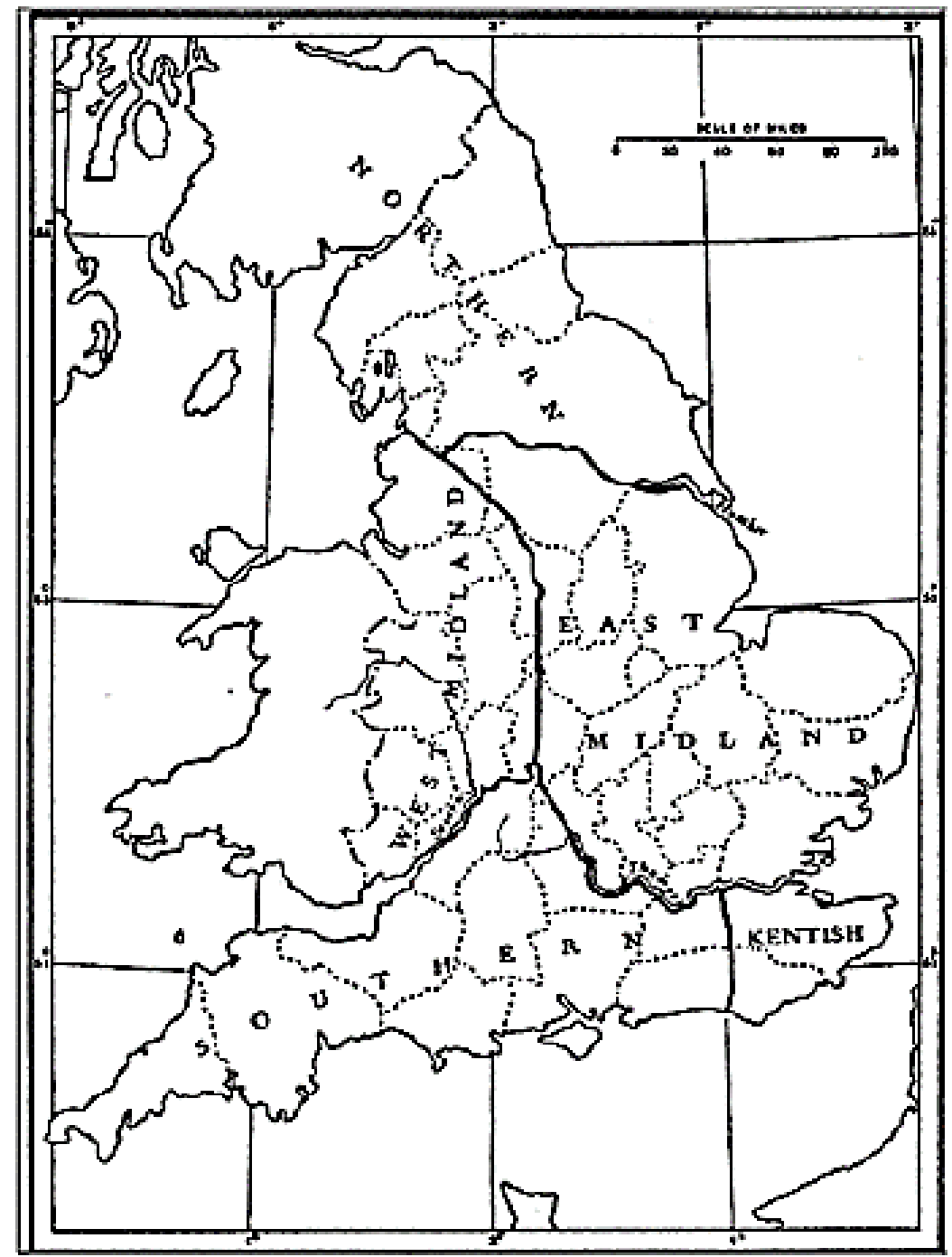

Source: BAUGH; CABLE (2005, p. 178).

Here are some changes that occurred in the sound system of Standard British English: /e:/ became /eI/ and /o:/ became /ov/ and then /əv/. In the short vowels, the sound $/ \mho /$, for instance, suffered some change in its phonetic realisation. Finally, concerning the consonants, Strang $(2015$, p. 111$)$ maintains that 
The consonant system was as now in its general structure, consisting of some twenty-five items; as we have seen, the distribution of $/ \mathrm{h} /$ and $/ \mathrm{h} /$ was phonemic only in stressed syllables, a kind of function not found for consonants in [Present-day English]; the $/ \mathrm{w} / ; / \mathrm{M} /$ contrast was less than general, and probably less widespread among standard speakers than today'.

While several accents can be found in the United Kingdom, and despite many voices against it (HINKEL, 2011; CRUTTENDEN, 2014; COOK, 2016), it is RP which is still the accent foreign students commonly learn in the United Kingdom and elsewhere where British English is the target variety (BROUGHTON et al., 1980; WAKELIN, 1977, as cited in WARDHAUGH, 1992; SHARWOOD-SMITH, 2007; YALLOP, 2007). Even presenting an argument against making RP the only accent to be taught in this context, Cook (2016, p. 99) recognises that it is the common accent in textbooks: " $R P$ (received pronunciation): the usual accent of British English given in books about English, spoken by a small minority in England". According to Sharwood-Smith (2007), the preference for RP is mostly due to the fact that, although not widely spoken, it is easily understood.

\section{MYTHS ABOUT GA AND RP IN BRAZIL}

In Brazil, there are myths about the North American and the British varieties of English concerning pronunciation. Apparently, at least one of them, namely the direct association of the English language exclusively with people from the United States of America, is deep-rooted in the history of the Christian church in the country.

Since 1500, Brazil has been the target of foreign Christian missionaries. According to Baird (1979, as cited in LEE, 2003), the Roman Catholic clerics, members of Pedro Álvares Cabral's expedition, were the first to enter the country. In the $17^{\text {th }}$ century, they were followed first by missionaries sent by the French theologian, John Calvin, then by Dutch Protestants. In 1823, the German Lutherans founded the first Protestant church in Brazil (LEE, 2003). Other Protestant churches were later established by Scottish, English and North American (NA) missionaries (BARRETT, 1982; CARR, 1979; PRICE, 2004). According to Price (2004), American Southern Methodists, Presbyterians and Baptists began an American colony in 1866, in the interior of the State of São Paulo from where they would spread their roots throughout Brazil.

Johnstone (1993) reports that there are almost 3,400 NA missionaries currently working in Brazil. Furthermore, Copeland (1985) maintains that the NA Protestant missionaries currently working in Brazil outnumber their peers working in other parts of the world. This seems to be suggestive of a preference amongst NA missionaries for evangelising Brazilians, which in turn may be due to great allegiance to NA culture in Brazil.

Apart from the long-term NA missionaries stationed in the country, there is a host of other short-term ones: members of groups such as Let's Start Talking and student campaign groups from David Lipscomb University, Oklahoma Christian University, Freed-Hardeman University, and Harding University (LEE, 2003). Combined with the preaching of the Gospel, these missionaries have been working at various fronts (mainly on education and health care), all of which involving close contact with the people. Carr (1979) points out that Baptist missionaries managed to reach the Brazilian people through 
education. Likewise, Tucker (1983) reports about a couple of Seventh Day Adventist NA missionaries' annual trips through the Amazon River and its tributaries, nursing the sick and preaching the Gospel.

It seems, therefore, the overwhelming presence of American missionaries in Brazil has had more than a religious influence on many Brazilians. Nevertheless, one must consider that the hegemony of AE in this country has also been exacerbated by economic, political and cultural factors. After World War II, NA ideological profiles have been increasingly disseminated throughout the world by the power of the globalised world media based on American models, as Bayard, Weatherall, Gallois and Pittam (2001) make the point; and this country is not immune to that. It does not mean that Brazilians should pull down a "xenophobic blind" over the "American-way" showcase. Instead, they should be engaged in a continuous process of learning how to interact with it and the outside world in general without jeopardising their own identity. But this can only be achieved through reflective education (FREIRE, 1977, 1982, 2001).The immediate association of the English language solely with people from the United States of America is still frequently made in certain places around Brazil. So much so that if common people hear two or more foreigners speaking in English in the street, they normally report to their peers in these terms: "I've seen some Americans today"; despite the fact that it might well have been a German and a French person, or a Briton and an Australian having a conversation in English. Furthermore, the association is so strong that it appears that even those who are presumably well-informed on linguistic matters have succumbed to the power of the NA linguistic hegemony lying behind this myth. An ELT consultant from São Paulo, for example, on a training session about a new course book in a city in northern Brazil, used expressions such as "... in American English of course"; or "... with that strong British accent ..."; this latter carrying an overtone of mockery, as if it were a funny thing to speak with an English accent in Brazil. Recently, another ELT consultant from Belém ${ }^{4}$ said "All teachers ask me if we don't have an American version of this book", in response to a participant's query mainly concerned with the matter of accent during an Oxford course book presentation to a group of Amazonian teachers. Another myth existing among Brazilians regarding the British and American varieties of English is that the former is believed to be archaic, and the latter contemporary. Differently from the other, this myth seems to be a consequence of the overwhelming power of NA media (BAYARD et al., 2001; MARTIN, 2009; FEKETE, 2015), which appears to be intent (intentionally or otherwise) in shaping the world according to NA measures. In a study on accent attitudinal evaluation involving speakers from Australia, New Zealand and the United States of America, Bayard et al. (2001) suggest that NA media may be one of the factors influencing Australians and New Zealanders to rate more favourably GA vis-à-vis RP and their own accent. Similarly, in Brazil the deluge of American films, music, and television programmes appears to serve the purpose of fostering the contemporary-versus-archaic myth regarding the American and British varieties of English.

${ }^{4}$ Belém is one of the largest cities of northern Brazil. 
Whether or not the NA (chiefly spoken) media has also had an impact on "attitudinal patterns of accent allegiance"', to put it in Bayard et al. term, in Brazil, as it seems to be the case in New Zealand (BAYARD et al., 2001), remains to be seen. However, it is possible that the rapid and consistent spread of NA media content in Brazil has contributed to the stigmatisation of the British variety of English and the strengthening of the hegemony of the American variety throughout the country.

\section{THE FAVOURED ACCENT IN BRAZIL}

Recently, a new education model has been proposed by the Brazilian government. In this model, English is amongst the compulsory subjects to be taught at both private and state-funded schools (BRASIL, 2017). Nevertheless, even though there is no suggestion in the National Common Curricular Base ${ }^{5}$ about the variety of English on which teachers and students should focus in the classroom, the preference for the American variety of English seems undisputed.

ELT materials used in state schools and even federal universities are mostly published in American English. Throughout Brazil, the audio materials of textbooks that are used at primary- and secondary-school levels in state-funded school have been published in this variety since time immemorial. Take, for instance, the English textbooks which were approved by the National Textbook Programme ${ }^{6}$ for primary-school and lower-secondary-school students (for the triennial period of 2014-2016) and for upper-secondary-school students (for the triennial period of 2015-2017). With no exception, all of the textbooks selected prioritise American English spelling, and with the exception of one, It Fits (COUTO, 2015), the other selected textbooks capitalise on American accent: Alive! (MENEZES et al., 2012), Vontade de saber inglês (KILLNER; AMANCIO, 2012), Take Over (SANTOS, 2013) and Upgrade (AGA, 2010). This appears to be a clear example of the firm $A E$ grip on educational institutions in this country.

The AE series Hello! (MORINO; DE FARIA, 2000), published in São Paulo, also seems to be a good thermometer of Brazilian ELT professionals' preference for the American variety of English. The absence of any reference to the variety of English targeted in the series seems to be a strong indication of the authors' assumption about the preferred variety of English in Brazil. Moreover, even in Morino and De Faria's notes to the teacher there is evidence of American hegemony (my translation and italics of first sentence):

\section{CELEBRATIONS}

Activities involving typical North American celebrations enrich work in the classroom a great deal. We present three famous celebrations - Valentine's Day, Halloween and Thanksgiving Day-, each one of them followed by suggestions for activities that can be done on the respective dates of the celebrations (MORINO; DE FARIA, 2000, p. 13).

\footnotetext{
${ }^{5}$ National Common Curricular Base is a statutory document approved by the Brazilian Ministry of Education that provides guidelines for the construction of programmes of study for primary- and secondary-school students attending private and state-funded institutions.

${ }^{6}$ The PNLD, Programa Nacional do Livro Didático is a programme of the Brazilian government to select and distribute textbooks to state-funded pre-, primary- and secondary-school students.
} 
Perhaps the "bandwagon effect" in terms of allegiance to AE has blindfolded the authors of Hello! to the extent that they fail to recognise that only Thanksgiving originated in North American soil from the First Thanksgiving, in the Autumn of 1621, which, due to historic accounts of other thanksgiving services, and to differentiate it from them, might as well be light-heartedly called "First American Protestant Christian Thanksgiving North of Virginia and South of Maine", according to McKenzie (2013, p. 9).

In a study on accent preferences and the use of AE features in Hong Kong, Edwards (2016) found out that the speech of most of the 68 English and English Language/English Education undergraduate participants revealed some marks of AE. Moreover, the author suggests that the participants' preference for $A E$ is mostly due to the influence of American media. While necessitating empirical investigation, these results are suggestive of the source of the apparent preference for AE amongst Brazilians as a corollary of the NA global dominance in its various "guises" (BAYARD et al., 2001, p. 41). It is possible, therefore, that, because of the pervasiveness of NA influence in the country, Brazilians are becoming so much "Americanised" that if this study were replicated in Brazil (but this time comparing AE with, say, BE, Australian English and Guyanese English), the data would lead to one basic conclusion that Edwards (2016) has drawn from her study in a former British colony: overwhelming preference for the American accent.

$B E$, the other prestige variety of English which, together with $A E$, is still the popular variety in EFL classrooms around the world (KACHRU; SMITH, 2008; LEECH et al., 2009; ESLAMI; SEAWRIGHT; RIBEIRO, 2016), even if the "empire is crumbling" - to put it in Khon's (2011, p. 76) words. In Brazil, BE is only taught at the Cultura Inglesa schools, whose main aim seems to be the dissemination of the English culture, and in a few other language institutes throughout the country. Nevertheless, in terms of pronunciation, not even in these schools BE finds a safe haven, since many teachers at Cultura Inglesa speak with an American English accent. Thus, if Robert Burchfield has predicted it correctly, the future seems bleak for the British variety of English in Brazil and in the rest of the world: “... American English, not British English, will remain the major global form of English into the indefinite future" (BBC Story of English TV series, programme 1, as quoted in BAYARD et al., 2001, p. 44).

Ironically, however, it seems most of the advocates of the American variety in Brazil are ELT professionals who, in terms of accent, cannot be identified as speakers of any of these varieties of English, but a Brazilian one.

\section{IMPLICATIONS OF THE AMERICAN LINGUISTIC MONOPOLY FOR THE TEACHING OF ENGLISH IN BRAZIL}

\section{Some Problems Facing Teachers of English Who do not Speak With a North American Accent (Naeste) In Brazil ${ }^{7}$}

The dearth of the typical AE rhotic/r/, and flapped / $\mathrm{t} /$ as in words like car /ka:r/, and letter/'leţə/ respectively in the speech of some English language teachers working in Brazil seems to brand them as outsiders of the "Brazilian English-speaking community", and this seems to have caused them some distress in the classroom.

7 The group of non-American-English-speaking teachers referred to in this paper encompasses both nationals from various English-speaking countries and non-native English speakers. 
Firstly, it appears that the type of concern commonly expressed by youngsters in general in terms of fashion or fads is extensive to the prestige variety of English in which Brazilian EFL learners (BELL) choose to be trained. At this point, the NA global hegemony (BAYARD et al., 2001) - chiefly through the spoken media - is likely to play a major role in shaping BELL's ideology on their choice of a variety of English. The aforementioned untenable premises that $B E$ is too formal or not as contemporary as $A E$ is, for instance, might evoke questions in the minds of prospective English learners in Brazil, such as (1) Why should one waste their time and their money on a "doomed" variety of English? (2) Why should one learn to speak in an archaic accent at the peril of being laughed at? (3) Or why should one want to be excluded from the English-speaking "world community"? Although treading mostly on speculative grounds throughout this paper, the assumption here is that, given the choice, most BELL would rather take English lessons from an $\mathrm{AE}$-accent oriented teacher than from a BE-accent oriented one.

Secondly, and perhaps as a consequence of feeling rejected, Naeste, who speak with an RP accent (or whose speech displays some features of it), may sometimes have the impression that they are "swimming against the tide" or working on the revitalisation of a dying language, which is no matter of concern to its native speakers. Perhaps the English people themselves have contributed to the diffusion of myths involving $B E$ and $A E$. It seems they too have bent to the NA global linguistic hegemony, both in terms of pronunciation and lexicon.

In a survey conducted by the University of London on the apparent American influence on the word schedule, it was verified that thirty percent of the informants preferred the American /'skedzu:l/ to the British /'Jedzu:l/. Importantly, sixty-four percent of those favouring the American /sk/sound at the beginning of the word were youngsters and only eight percent of older informants preferred its British counterpart, the /J/ phoneme (KEYS, 1999, p. 25). It is not uncommon hearing, for instance, soccer supplanting football in the speech of BBC sports commentators. Many British singers also change their accent when performing to sound more like their American peers (NUNES; AZZI, 2017). Similarly, those who should apparently be zealously engaged in the maintenance of the quality of their 'standard' variety are currently making AE versions of their BE ELT materials, being the Headway, Inside Out and English File series good examples of that (SOARS; SOARS, 2003; KAY; JONES, 2003; LATHAM-KOENIG; OXENDEN, 2014). This seems in turn to exacerbate the BE-accent "cringe" and strengthen the $A E$-accent global dominance, besides being clear evidence of the NA post-war influence worldwide.

Thirdly, NAESTE can find themselves in even more delicate a position when working for institutions where AE is the overtly chosen variety. These teachers are often inquired about words they pronounce differently from those on class audio/video media. Questioning, almost always contrasting the teacher's accent with that (chiefly from NA films and television programmes) to which BELL are exposed daily, such as 
$\mathrm{S}$ - 'Teacher! How do you say trinta in English?'

T - 'Thirty' /'Өз:tr/.

$\mathrm{S}$ - 'But in the movies yesterday, and I heard a guy say something like thirty/' $\theta$ z:rţi/. Is it correct? Which one is most commonly used?'8

is not uncommon in the English language classroom in Brazil. Additionally, after a brief explanation about some of the differences between $B E$ and $A E$, the typical ensuing question is voiced: "Can BE and AE speakers understand each other without any communication problems?" However, when working for an institution where the British variety is taught there seems to be less inquiry into the matter of accent, unless the teacher himself or herself raises the issue. On a cautionary note, however, it is important to point out that, although these suggestions are based on the author's personal experience and observations of more than ten years in the EFL classroom, confirming them may require systematic empirical research.

Finally, and perhaps more seriously, this overt BELL allegiance towards AE accent may even jeopardise NAESTE's career in Brazil if the ruthless market laws are properly applied by ELT institutions around the country. In other words, it will not be surprising if the accent with which one speaks becomes a decisive feature in the choice of teachers of English in Brazil and elsewhere; after all it seems "the tree is inclined as $A E$ is bent".

\section{Some Suggestions to Tackling Problems Regarding Accent-Bar}

Given the bleak scenario described above and elsewhere (BAYARD et al., 2001) concerning $B E$ vis-à-vis $A E$, one might be quick to suggest that one "immediate" solution to the problem faced by NAESTE where AE is the target variety would be the engagement in an accent re-education process as an attempt to be in line with the NA variety of English. Baugh and Cable (2005) imply that this is not as daunting a task to achieve as has been believed, and they suggest it reveals the perception of language standardisation. Moreover, it is part of an attempt to secure a place in a group which is regarded as having a higher status position:

[...] as people lift themselves into a different economic or intellectual or social level, they are likely to make an effort to adopt the standards of grammar and pronunciation of the people with whom they have identified, just as they try to conform to fashions and tastes in dress and amusements. However superficial such conformity might be, people are as careful of their speech as of their manners. Awareness that there are standards of language is a part of their social consciousness (BAUGH; CABLE, 2005, p. 188).

Nevertheless, assuming that ethnicity strength and strong ideological views can be imposing variables in terms of accent allegiance, the idea of acquiring pronunciation habits (to put it in Broughton et al.' terms) is likely to be opposed by Naeste with strong ethnic identity (BRESNAHAN et al., 2002) and anti-American sentiments. Thus, it is likely that those Naeste antagonising the 'Americanisation' of Bell would be reluctant to bending to this instrument of NA domination.

${ }_{8}^{8}$ This is a concocted dialogue. 
Stern (1992) points out that there is no need for accent change when teachers do not share the classroom target-language variety, insofar as modern technological devices can be instrumental in exposing modern foreign language (MFL) learners to their preferred language variety. This can be achieved through the assignment of commercial films, radio and television programmes as extra-class (or otherwise) learning activities. While Brown (1994, p. 121) prescribes these "[...] to help [...] compensate for the lack of ready communicative situations right outside the classroom door [...]", they can serve the purpose of aligning MFL learners pronunciation with the variety of their preference. The frequent use of the recorded material commonly accompanying MFL textbooks in the classroom can be invaluable in shaping MFL learners' accent.

Stern (1992) suggests inviting native speakers to the classroom as a means of developing MFL learner communicative competence. Perhaps this is also likely to be an important tool in consolidating learners' accent. Yet another way of defining accent irrespective of the variety of the target language that the MFL teacher speaks seems to be by joining exchange programmes, or immersion courses. Although the participation in these kinds of events may be a common practice amongst Brazilian upper-class MFL learners, it is obviously unrealistic for most Bell for pecuniary reasons. This approach is also advocated by Allen and Valette (1994) as a means of enhancing MFL teachers' aural/oral skills:

Professional foreign-language teachers continually strive to improve their competence in the second and often third language. They try to get abroad at least once every five years, perhaps taking advantage of the low-cost charter flights of the professional organizations.... They try to get to foreign films, possibly seeing them two or three times, once for entertainment and subsequently as a means of increasing their audio-lingual skills. ... If possible, they listen regularly to radio broadcasts in the foreign language, on shortwave or ... local stations. They may even invite (and pay) a willing native speaker residing in their community to visit their language classes from time to time to note any mistakes they make (ALLEN; VALETTE, 1994, p. 4).

Finally, there are speech technologies and the Internet at the disposal of Naeste to help their students on pronunciation improvement. Despite their limitations, computer-assisted pronunciation training systems can help MFL learners practise, model and get feedback on their pronunciation (HINCKS, 2015). They can also use the Internet to access a wide range of visual, oral or written resources to work on pronunciation and thus on accent shaping. It appears that these tools can be a realistic way to prevent Naeste accent 'contaminating' MFL learners' speech.

\section{CONCLUSION}

Brazil has been an independent state for more than 190 years, and after the Portuguese language suppressed the indigenous languages, it has become the official language of the country and the mother tongue of most Brazilians (CHAUNU, 1983). Therefore, other languages (including some indigenous languages) are learnt as additional languages in Brazil. This means to say that, differently from the example given earlier in this paper involving a Singaporean student, there should be no reason why one should 
be technically denied the right to select the variety of any target language one chooses to learn. Why, for instance, should Brazilians be tacitly denied the choice of a different variety of English other than the American one? Broughton et al. (1980, p. 7) suggestion that "the choice of variety is partly influenced by the availability of teachers, partly by geographical location and political influence" is an interesting one. But it is only partially tenable, especially in terms of territorial proximity, otherwise people from the north of Brazil, for instance, would be willing to learn Guyanese English, which does not seem to be the case, despite the fact that Guyana is the nearest English-speaking country, factually bordering the northern Brazilian states of Roraima and Pará (BELTRAME, 1997). Instead, one should be quick to point out that such choice is essentially influenced by economic power. This is clearly seen in the somewhat intriguing attitude (from an ideological perspective) of many British ELT authors writing American English versions of their original English textbooks.

Although some may disagree about the GA-RP tension in Brazil, categorisations such as American English and British English established by ELT publishers and distributors around the country seem to be irrefutable evidence of it. Thus, it appears that the decanted assertion "We are beyond that" amongst Brazilian ELT professionals, when inquired about this tension, can still be treated with some scepticism.

Fortunately for non-American-English-speaking teachers of English working in Brazil, it seems speaking with a General American accent is no more a prerogative of some North Americans than speaking with a Received Pronunciation accent is of some English people. In other words, any attempt made by ESL or EFL learners at speaking with either GA or RP is almost certain to be frustrated by the barriers of the idiosyncrasies of one's mother tongue, as Medgyes makes the point:

[...] for all their efforts, non-native speakers can never achieve a native speaker's competence.... A select few come quite close to native competence ... but sooner or later they are halted by a glass wall. Few have managed to climb over it. Joseph Conrad, alias Józef Teodor Konrad Korzeniowaski, was one, but such immortals are exceptions to the rule (MEDGYES, 1992, p. 342).

Assuming this point of view reflects the learning experience of most Brazilian learners of English, instead of favouring GA in detriment of RP (or otherwise), it seems wise to subscribe to a "third route", namely non-discriminatory teaching of other varieties of English in Brazil. This seems to be in line with Maturana's (2006) conciliatory view on how to cope with different perceptions of reality. He suggests that the self should never use their cognitive assertions to annihilate the other, and that the creation of "a different shared domain" is a way of avoiding "mutual destruction" (MATURANA, 2006, p. 122).

\section{REFERENCES}

ABERCROMBIE, David. Studies in Phonetics and Linguistics. London: Oxford University Press, 1965. AGA, Gisele (ed.). Upgrade. 2, língua estrangeira moderna: inglês. São Paulo: Richmond, 2010.

ALLEN, Edward D.; VALETTE, Rebecca M. Classroom Techniques: Foreign Languages and English as a Second Language. $3^{\text {rd }}$ ed. Illinois: Waveland Press, 1994.

BARRETT, David B. World Christian Encyclopaedia. Nairobi: Oxford University Press, 1982.

BAUGH, Albert C.; CABLE, Thomas. A History of the English Language. $5^{\text {th }}$ ed. London: Routledge, 2005. 
BAYARD, D. et al. Pax Americana? Accent Attitudinal Evaluations in New Zealand, Australia and America. Journal of Sociolinguistics, v. 5, n. 1, p. 22-49, 2001.

BELTRAME, Zoraide V. Geografia geral do Brasil. $12^{\text {nd }}$ ed. São Paulo: Ática, 1997.

BERNS, Margie. Contexts of Competence: Social and Cultural Considerations in Communicative Language Teaching. New York: Springer Science \& Business Media, 2013.

BRASIL. Ministério da Educação. Base Nacional Comum Curricular (BNCC): educação é a base. Brasília, MEC/Consed/Undime, 2017. Disponível em: http://portal.mec.gov.

br/busca-geral/323-secretarias-112877938/orgaos-vinculados-82187207/62391-bncc-ensino

-medio. Acesso em: 15 ago. 2018.

BRESNAHAN, M. et al. Attitudinal and Affective Response Toward Accented English. Language \& Communication, n. 22, p. 171-185, 2002.

BROOK-HART, Guy; JAKEMAN, Vanessa; JAY, David. Complete ELTS: Bands 6.5-7.5 - Teacher's Book. Cambridge: Cambridge University Press, 2013.

BROUGHTON, Geoffrey et al. Teaching English as a Foreign Language. $2^{\text {nd }}$ ed. New York: Routledge, 1980. BROWN, H. Douglas. Teaching by Principles. New Jersey: Prentice Hall, 1994.

CARR, H. Joseph Jr. A Missiological Comparison of the Pentecostals, Baptists, and Churches of Christ in Brazil. Memphis: TN, 1979.

CHAUNU, Pierre. História da América Latina. 5. ed. Translated by M. U. Rodrigues. São Paulo: Difel, 1983. COOK, Vivian. Second Language Learning and Language Teaching. $5^{\text {th }}$ ed. New York: Routledge, 2016.

COPELAND, Roger L. A Descriptive Analysis of Teams Working in Brazil. Memphis, TN; NP, 1985.

COUTO, Ana Luiza. It fits. 8o ano, língua estrangeira moderna: inglês. 2. ed. São Paulo: Edições SM, 2015. CRUTTENDEN, Alan. Gimson's Pronunciation of English. $8^{\text {th }}$ ed. Abingdon: Routledge, 2014.

EDWARDS, Jette G. H. Accent Preferences and the Use of American English Features in Hong Kong: a Preliminary Study. Asian Englishes, v. 18, n. 3, p. 197-215, 2016.

ESLAMI, Zohreh R.; SEAWRIGHT, Leslie; RIBEIRO, Angelica. Attitudes Toward English as Lingua Franca: University Students in Qatar. In: SEAWRIGHT, L.; HODGES, A. (ed.). Learning Across Borders: Perspectives on International and Transnational Higher Education. Newcastle upon Tyne: Cambridge Scholars Publishing, 2016. p. 132-148.

FEKETE, Adrienn. Hungarian High School Students' Attitudes Towards English Varieties in Listening Comprehension Tests. In: KREVELJ, S, L.; DJIGUNOVIC, J. M. (ed.). UZRT 2014: Empirical Studies in Applied Linguistics. Zagreb: FF Press, 2015. p. 54-69.

FREIRE, Paulo. Ação cultural para a liberdade e outros escritos. 2. ed. Rio de Janeiro: Paz e Terra, 1977.

FREIRE, Paulo. Pedagogia do oprimido. 11. ${ }^{\mathrm{t}}$ ed. Rio de Janeiro: Paz e Terra, 1982.

FREIRE, Paulo. A importância do ato de ler. 42. ed. São Paulo: Cortez, 2001.

HINCKS, Rebbeca. Technology and Learning Pronunciation. In: REED, M. R.; LEVIS, J. M. (ed.). The Handbook of English Pronunciation. Oxford: Wiley Blackwell, 2015. p. 505-519. .

HINKEL, Eli (ed.). Handbook of Research in Second Language Teaching and Learning. New York: Routledge, 2011. V. 2.

HUDSON, Richard A. Sociolinguistics. Cambridge: Cambridge University Press, 1980.

JOHNSTONE, Patrick. Operation World: Grand Rapids. MI: Zondervan Publishing House, 1993.

KACHRU, Yamuna; NELSON, Cecil L. World Englishes in Asian Contexts. Hong Kong: Hong Kong University Press, 2006.

KACHRU, Yamuna; SMITH, Larry E. Cultures, Contexts, and World Englishes. New York: Routledge, 2008.

KAY, Sue; JONES, Vaughan. American Inside Out: Student's Book, Upper Intermediate. Oxford: Macmillan, 2003.

KEYS, K. J. Whose English is it Anyway? New Routes, n. 8, p. 24-25, 1999.

KHON, Kurt. English as a Lingua Franca and the Standard English Misunderstanding. In: DE HOUWER, A.; WILTON, A. (ed.). English in Europe Today: Sociocultural and Educational Perspectives. Amsterdam; Philadelphia: John Benjamins, 2011. p. 71-94.

KILLNER, Mariana; AMANCIO, Rosana. Vontade de saber inglês, 6 ano. 1. ed. São Paulo: FTD, 2012.

LADEFOGED, Peter; JOHNSON, Keith. A Course in Phonetics. $6^{\text {th }}$ ed. Boston: Wadsworth, Cengage Learning, 2011.

LATHAM-KOENIG, Christina; OXENDEN, Clive. American English File: Level 5 Student Book Pack. Oxford: Oxford University Press, 2014. 
LEE, S. Brazil - a History of Missions. Harding University: Center for World Missions, 2003. Retrieved from: http://www.harding.edu/cwm/Resources/articles/brazil.htm. Accessed on: 6 dec. 2017.

LEECH, Geoffrey. et al. Change in Contemporary English: a Grammatical Study. Cambridge: Cambridge University Press, 2009.

LODGE, R. Anthony. French: From Dialect to Standard. London: Routledge, 1993.

LOPRIORE, Lucilla; VETTOREL, Paola. Promoting Awareness of Englishes and ELF in the English Language Classroom. In: BOWLES, H.; COGO, A. (ed.). International Perspectives on English as a Lingua Franca: Pedagogical Insights. New York: Springer, 2016. p. 13-34.

LYONS, John. Language and Linguistics: an Introduction. Cambridge: Cambridge University Press, 1981.

MCKENZIE, Robert T. The First Thanksgiving: What the Real Story Tells us About Loving God and Learning From History. Downers Grove: Inter Varsity Press, 2013.

MARTIN, Elizabeth A. World Englishes in the Media. In: KACHRU, B.; KACHRU, Y.; NELSON, C. (ed.). The Handbook of World Englishes. Sussex: Wiley-Blackwell, 2009. p. 583-600.

MATURANA, Humberto. Cognição, ciência e vida cotidiana. Organização e tradução Cristina Magro e Victor Paredes. Belo Horizonte: UFMG, 2006.

MEDGYES, Peter. Native or Non-Native: Who's Worth More? ELT Jornal, v. 46, n. 4, p. 340-349, 1992.

MENEZES, Vera et al. Alive! Língua estrangeira moderna: inglês, 6o ano. 1. ed. São Paulo: UDP, 2012.

MORINO, Eliete C.; DE FARIA, Rita B. Hello! São Paulo: Ática, 2000.

NUNES, Mariana B.;AZZI, Júlia. N. Did America Invade the Beatles as They Invaded America? - a Comparative Analysis on the Beatles' Accent in Former and Later Years. Entrepalavras, n. 7, p. 46-65, 2017.

PRICE, Donald E. A Comparative Analysis of the Growth of the Brazilian Baptists and the Assembly of Gods in Metropolitan São Paulo, 1981-1990. 2004. 329p. (Doctoral dissertation, College of Theology of the University of South Africa, Pretoria, South Africa).

Retrieved from: http://uir.unisa.ac.za/bitstream/handle/10500/2213/thesis.pdf. Accessed on: 6 dec. 2017.

QUIRK, Randolph; WIDDOWSON, H. G.; CANTÚ, Yolande. English in the World - Teaching and Learning the Language and Literature. London: Cambridge University Press, 1985.

RAY, Rimaletta. Americanize your Language: Emotionalize Your Speech. West Hollywood: Nova Press, 2016.

ROBERTSON, Stuart; CASSIDY, Frederic G. The Development of Modern English. $2^{\text {nd }}$ ed. Englewood Cliffs: Prentice-Hall Inc, 1954.

ROGERSON-REVELL, Pamela. English Phonology and Pronunciation Teaching. London: Bloomsbury, 2013. ROMAINE, Suzanne. Linguistic diversity and language standardization. In: HELLINGER, M.; PAUWELS, A. (ed.). Handbook of Language and Communication: Diversity and Change. Berlin: Walter de Gruyter, 2007. p. 685-714.

RYAN, Ellen. B.; GILES, Howard; SEBASTIAN, Richard J. An Integrative Perspective for the Study of Attitudes Towards Language Variation. In: RYAN, E. B.; GILES, H. (ed.). Attitudes Towards Language Variation: Social and Applied Contexts. London: Edward Arnold, 1982. p. 1-19.

SANTOS, Denise. Take Over. 1, língua estrangeira moderna: inglês. São Paulo: Escala Educacional, 2013.

SHARWOOD-SMITH, Michael. British Shibboleths. In: RONOWICZ, E.; YALLOP, C. (ed.). English: one Language, Different Cultures. 2. ed. London: Continuum. 2007. p. 43-78.

SKANDERA, Paul; BURLEIGH, Peter. A Manual of English Phonetics and Phonology. $2^{\text {nd }}$ ed. Tübingen: Narr Francke Attempto Verlag GmbH + Co. KG, 2011.

SOARS, Liz; SOARS, John. American Headway: 3A. Oxford: Oxford University

Press, 2003.

STERN, Hans. H. Issues and Options in Language Teaching. Oxford: Oxford University Press, 1992.

STRANG, Barbara M. H. A History of English. Abingdon: Routledge, 2015.

TRUDGILL, Peter. Dialects in Contact. Oxford: Blackwell, 1986.

TUCKER, Ruth A. From Jerusalem to Irian Jaya: a Biographical History of Christian Missions. Grand Rapids, MI: Zondervan, 1983.

WARDHAUGH, Ronald. An Introduction to Sociolinguistics. $2^{\text {nd }}$ ed. Oxford: Basil Blackwell, 1992.

YALLOP, Colin. English Around the World. In: RONOWICZ, E.; YALLOP, C. (ed.). English: one Language, Different Cultures. 2. ed. London: Continuum. 2007. p. 24-42. 